Positions moyennes des étoiles de comparaison.

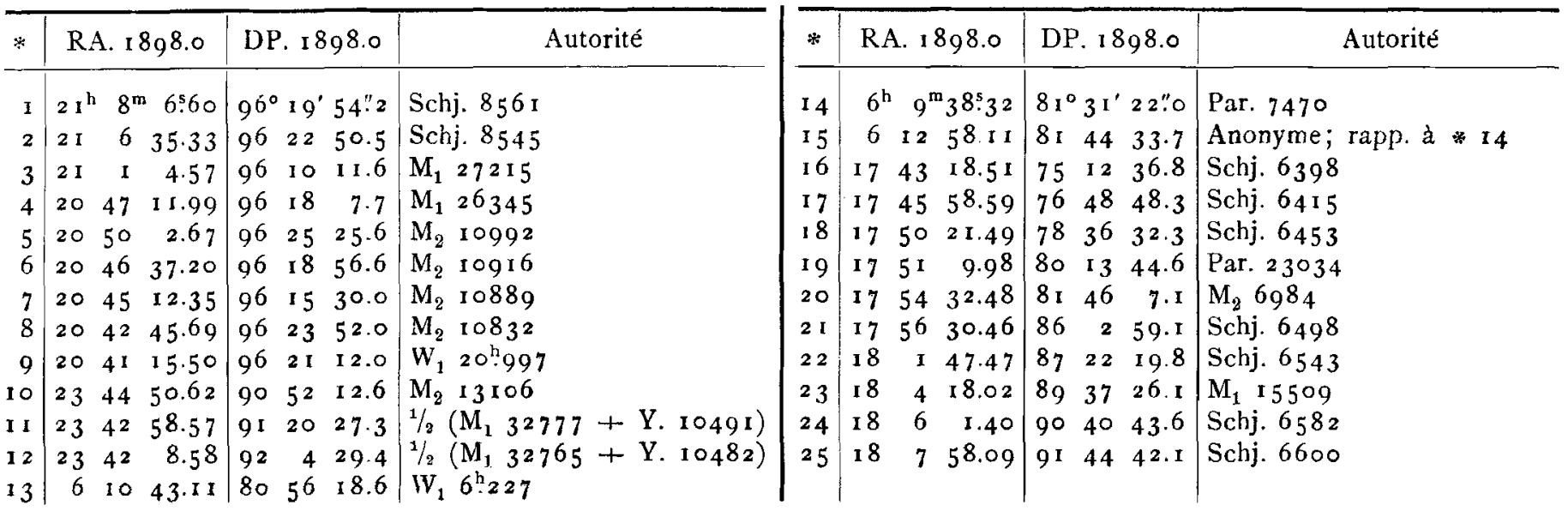

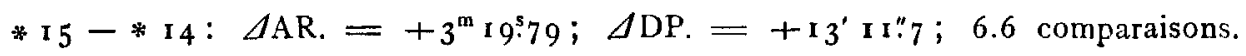

Besançon, le 26 Novembre 1898 .

Le Directeur de l'Observatoire:

$$
\text { L. F. Gruey. }
$$

Beobachtungen des Cometen 1898...(Brooks Oct. 20)

\begin{tabular}{|c|c|c|c|c|c|c|c|c|c|c|}
\hline 1898 & M.Z. Kiel & $\Delta a$ & $\Delta \delta$ & Vgl. & $\alpha$ app. & $\log p \cdot \Delta \mid$ & & $\log p \cdot \Delta \mid$ & d l. app. & $*$ \\
\hline $\begin{array}{l}6 \\
6\end{array}$ & 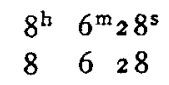 & $\begin{array}{l}-0^{m} 19^{5} 62 \\
-035.80\end{array}$ & $\begin{array}{l}\text { - II'23.4 } \\
-\quad 436.9\end{array}$ & $\begin{array}{l}7 \\
7\end{array}$ & $\begin{array}{l}\text { I } 7^{\mathrm{h}} 37^{\mathrm{m}} 43^{\mathrm{s}} \circ 2 \\
173743.68\end{array}$ & $\begin{array}{l}9.553 \\
9.553\end{array}$ & $\begin{array}{l}\text { + } 16^{\circ} 44^{\circ} 0.4 \\
+164358.2\end{array}$ & & $\begin{array}{l}+2.01+4.9 \\
+2.01+4.9\end{array}$ & \\
\hline
\end{tabular}

am Refractor der Sternwarte in Kiel.

\begin{tabular}{|c|c|c|c|}
\hline$*$ & $\alpha 1898.0$ & $\delta$ I 898.0 & Autorität \\
\hline I & $17^{\mathrm{h}} 3^{8^{\mathrm{m}}} \quad 0^{5} 63$ & $\begin{array}{l}+16^{\circ} 55^{\prime} 18.9 \\
+164830.2\end{array}$ & $\begin{array}{l}\text { AG. Berlin A. } 6404 \\
\text { AG. Berlin A. } 6405\end{array}$ \\
\hline
\end{tabular}

Mittlere Oerter der Vergleichsterne.

Kiel, 1898 Nov. I 4 .

F. Ristenpart.

\title{
Variations in the Spectrum of the Orion Nebula.
}

Some doubt having been expressed as to the reality of variations which have been observed in the spectrum of the Orion Nebula, I made some visual observations with reference to this question on the night of Dec. 12, with a spectroscope attached to the 36 inch refractor.

The slit was first placed on the nebulosity surrounding the star Bond 734. The night being hazy, only a single line was visible. It was occulted by the coarse micrometer wire, and, on throwing in the light from a hydrogen tube, was identified as $H \beta$.

The slit was then placed on the Huyghenian region, near the trapezium. The usual spectrum was well seen. $H \beta$ and the second nebular line $(\lambda=4959)$ were about equally bright; the chief line $(\lambda=5007)$ was several times brighter than either.

The intensity of the spectrum was then diminished by contracting the vertical aperture of the spectroscope, the resolving power remaining therefore unchanged. When the brightness was sufficiently reduced, $H \beta$ and the second line disappeared, the chief nebular line being then alone visible.

In other words, with a sufficiently feeble spectrum the $H \beta$ line was alone visible in one part of the nebula, and the chief line was alone visible in another part. This result. is inexplicable on physiological grounds. It can only be due to real differences in the spectrum of the nebula.

Lick Observatory, University of California, 1898 Dec. 22.

Ұames E. Keeler.

lnhalt zu Nr. 354 I. H. Kimura. On the calculation of star-factors for the mean declination of a pair of stars in zenith telescope observations. 193. - S. Oppenheim. Bemerkung zu dem Aufsatz von Herrn Dziobek in A. N. 35 I 4. 199. - O. Stone. Observations of the Satellites of Saturn. 20I. - L. Cruls. Observations de Comètes. 203. - L. F. Gruey. Observations de planètes et comètes. 205. - F. Ristenpart. Beobachtungen des Cometen 1898...(Brooks Oct. 20). 207. - F. E. Keeler. Variations in the Spectrum of the Orion Nebula. 207.

Geschlosgen 1899 Jan. 2r. Herausgeber: H. Kreutz. Druck von C. Schaid, Expedition: Kiel, Niemannsweg roz. 